\title{
Social attitudes towards roadside advertising
}

\author{
Anna Olejniczak-Serowiec ${ }^{1, *}$, Norbert Maliszewski ${ }^{1}$, and Kinga Ziętek ${ }^{1}$ \\ ${ }^{1}$ University of Warsaw, Faculty of Psychology, Warsaw, Poland
}

\begin{abstract}
Public opinion is not always consistent with expert opinion. A nationwide CAWI research project was conducted in order to verify Polish drivers' opinion on roadside advertising and their experience concerning distraction and loss of situational awareness. Research results show that although many drivers have experienced partial loss of situational awareness, most of them are not convinced of the need to restrict roadside advertising. Nonetheless, on the basis of the results, we can identify the most distracting characteristics of roadside advertising as well as socially acceptable rule changes.
\end{abstract}

\section{Introduction}

The idea behind advertising is to have the message memorized or at least acquired by the addressee - a potential client. On the other hand, the effectiveness of driving may decrease as a result of distraction. This leads to the question as to how roadside advertisements influence road safety. Statistical analysis of the number of accidents and behaviour changes reveal some decrease in driver effectiveness in the presence of roadside advertising [1,2], however, other data suggest the contrary [3]. Driving simulator studies show that in the context of roadside advertising, drivers show more behaviours resulting from inattention [4], memorize traffic signs less effectively and feel more tired [5-7], but in each of the studies, some other indicators of driving effectiveness remain unaffected.

As the pure presence of the roadside advertisement does not make a consistent difference in driving behaviour, the question is which roadside advertisement characteristics makes it distracting.

As far as technical characteristics (e.g. light emission, location) are concerned, there is quite a lot of data available [2,7-9]. The influence of the content of roadside advertising on road safety, however, is less described in the literature. Simulator studies accompanied by eye tracking methods prove that advertisements (i.e. information signs with service points' logotypes) are more distracting than traffic signs[10]. Additionally, their distractive value increases with the complexity of the sign (i.e. the number of logotypes) [11]. Another perspective on the complexity of advertisement content was adapted by Scheiber's team [12], according to whom, the danger from roadside advertising occurs when it consists of eight or more words.

Although, the aforementioned studies are a voice in the discussion on the role of advertising content for road safety, they remain focused on technicalities rather than the real substance of the stimuli.

Research on advertising mechanisms proves that the emotional load of advertising influences the addressee's cognitive processes [13]. Consequently, it seems reasonable to hypothesize that the emotional load of roadside advertising may influence driver behaviour

\footnotetext{
"Corresponding author: anna.olejniczak@psych.uw.edu.pl
} 
and result in lower road safety. This problem became central to Megias' research. In his studies, the influence of negative emotional load turns out to be particularly significant for driving drivers' attention away from the road, but also for decreasing reaction time to danger and the number of speeding decisions when yellow light comes up (compared to positive stimuli exposition) $[14,15]$.

Because the emotional message is an important factor in advertising and is also a proven attention distractor, it was decided that more research on roadside advertisement content, especially the emotional load, would be helpful with understanding the role of roadside advertising for road safety.

\section{Study I}

The study was inspired by research reports which prove that drivers do consciously pay attention to roadside advertisements and are well aware of the distraction it causes [2,4]. It was designed to explore Polish drivers' experience with roadside advertising with reference to particular types of contents used in advertising.

\subsection{Participants and procedure}

The data come from a nationwide CAWI research project. All the participants were the research panel's voluntary respondents and were rewarded with a certain amount of points, which they may subsequently exchange for rewards.

Of the total of 1,095 participants, 428 were female and 667 - male. Participants' age varied between 18 and $80(\mathrm{M}=41.43 ; \mathrm{SD}=14.29)$ and their active driving experience - from less than one year $(n=64 ; 5.8 \%)$ to 51 years with a mean of $16.77(\mathrm{SD}=11.56)$ in the later more experienced group $(\mathrm{n}=1031 ; 94.2 \%) .718$ (65.6\%) of the participants declared daily use of the car and $234(21.4 \%)$ declared that they drive a car at least once a week. The eyesight condition was also controlled, $39.5 \%$ of the participants declared some impairment.

All the participants filled in an online survey. First, they were asked a set of questions concerning demographics, driving experience and eyesight condition. Subsequently, a number of questions were presented concerning their experience with roadside advertising, as well as their experience with advertisements of particular types of content. Seven types of contents were considered in the study: positive emotional load, negative emotional load, sexual, humorous, riddles or curious contents, sales offers and contents which resemble traffic signs (each illustrated with a photo).

All the questions were divided into two types: YES/NO questions designed to diagnose what percentage of respondents has ever experienced the described situation and frequency questions in which respondents answered on a six point Likert scale (from never to always), how often they face the situation, the answer I don't know was also possible.

\subsection{Results}

Frequency analysis proved that Polish drivers do sometimes pay attention to roadside advertising $(\mathrm{M}=2.72, \mathrm{SD}=1.41)$ as well as consciously read it $(\mathrm{M}=2.26 ; \mathrm{SD}=1.44)$. Among $42.8 \%$ of respondents who declared they had experienced a distraction due to roadside advertising, the mean value for attention distraction frequency was $\mathrm{M}=3.02(\mathrm{SD}=1.28)$, they also reported some difficulties in road situation understanding $(\mathrm{M}=2.66 ; \mathrm{SD}=1.41)$. The frequency analysis is quoted in Table 1 . No statistically significant sex differences were identified, except conscious advertisement reading $(\mathrm{t}=-2.189 ; \mathrm{p}=0.029)$, which men $(\mathrm{M}=2.34$; $\mathrm{SD}=1.44)$ declare more frequent than women $(\mathrm{M}=2.14 ; \mathrm{SD}=1.43)$. Driving experience, 
education level and eyesight condition did not affect the results either. ANOVA analysis revealed a significant difference between different age groups for paying attention to roadside advertisement $(F(4)=4.71, p=0.001)$ and conscious reading $(F(4)=6.99, p<0.001)$. Post hoc analysis with NIR test shows that drivers over 54 years scored significantly lower in these questions $(\mathrm{M}=2.37 ; \mathrm{SD}=1.42 ; \mathrm{M}=1.85 ; \mathrm{SD}=1.41)$ than all the other age groups with mean values varying from 2.74 to 2.87 for paying attention to advertisements and from 2.25 to 2.47 for conscious reading.

Table 1. Frequency analysis for attention distraction, conscious reading of roadside advertisements and difficulties in situation understanding.

\begin{tabular}{|c|c|c|c|c|c|c|c|c|}
\hline & $\begin{array}{l}\text { Don’t } \\
\text { know }\end{array}$ & Never & $\begin{array}{l}\text { Very } \\
\text { rarely }\end{array}$ & $\begin{array}{l}\text { Rather } \\
\text { rarely }\end{array}$ & $\begin{array}{c}\text { Neiter } \\
\text { rarely } \\
\text { nor } \\
\text { often }\end{array}$ & $\begin{array}{c}\text { Rather } \\
\text { often }\end{array}$ & $\begin{array}{l}\text { Very } \\
\text { often }\end{array}$ & Always \\
\hline Paying attention & $2,8 \%$ & $5,7 \%$ & $15,9 \%$ & $20,5 \%$ & $24,3 \%$ & $22,5 \%$ & $6,1 \%$ & $2,3 \%$ \\
\hline $\begin{array}{l}\text { Conscious } \\
\text { reading }\end{array}$ & $2,9 \%$ & $11,5 \%$ & $20,7 \%$ & $22,6 \%$ & $22,6 \%$ & $13,5 \%$ & $5 \%$ & $1,2 \%$ \\
\hline \multicolumn{9}{|c|}{$\begin{array}{c}57,2 \% \text { of respondends have never experienced attention distraction from roaside advertisement; } \\
\text { the data below desribe the remaining } 42,8 \%(\mathrm{n}=469)\end{array}$} \\
\hline $\begin{array}{l}\text { Attention } \\
\text { distraction }\end{array}$ & $1,9 \%$ & $0,4 \%$ & $11,9 \%$ & $24,3 \%$ & $24,5 \%$ & $25,4 \%$ & $9 \%$ & $2,6 \%$ \\
\hline $\begin{array}{l}\text { Situation } \\
\text { understanding } \\
\text { difficulties }\end{array}$ & $2,8 \%$ & $6,8 \%$ & $14,9 \%$ & $22,4 \%$ & $23,5 \%$ & $20,9 \%$ & $7,9 \%$ & $0,9 \%$ \\
\hline
\end{tabular}

T-test analysis for dependent samples revealed statistically significant differences in a subjectively evaluated frequency of attention distraction of different content. Mean values for the question "How often do you happen to be distracted by..." are presented in Table 2, and t-test values are presented in Table 3. Group comparison between men and women revealed that women perceive emotionally negative advertisements as more distractive than men $(\mathrm{t}=4.427 ; \mathrm{p}<0.001 ; \mathrm{M}=3.15$ and $\mathrm{M}=2.43)$, a similar difference occurs for riddles $(\mathrm{t}=1.970 ; \mathrm{p}=0.049 ; \mathrm{M}=3.01$ and $\mathrm{M}=2.81)$. Males find sexual content mores distractive than women $(\mathrm{t}=-3.324 ; \mathrm{p}=0.001, \mathrm{M}=3.02$ and $\mathrm{M}=2.67)$. When age and length of driving experience were taken into account, a negative correlation was observed, however emotionally negative content and sales offers did not fit the trend. The values of Pearson correlations are presented in Table 4.

Table 2. Frequency of distraction experienced from advertisements with different content.

\begin{tabular}{|c|c|c|c|c|c|c|c|}
\hline & Positive & Negative & Sexual & Humorous & $\begin{array}{c}\text { Resembling } \\
\text { road signs }\end{array}$ & $\begin{array}{c}\text { Sales } \\
\text { offer }\end{array}$ & Riddles \\
\hline Mean & 2,46 & 2,88 & 2,88 & 2,77 & 2,78 & 2,37 & 2,89 \\
\hline $\begin{array}{c}\text { Standard } \\
\text { deviation }\end{array}$ & 1,44 & 1,57 & 1,66 & 1,49 & 1,54 & 1,55 & 1,54 \\
\hline
\end{tabular}


Table 3. Differences between declared frequency of distraction experienced from advertisements with different content.

\begin{tabular}{|l|c|c|c|c|c|c|c|}
\hline & Positive & Negative & Sexual & Humorous & $\begin{array}{c}\text { Resembling } \\
\text { road signs }\end{array}$ & Sales offers & Riddles \\
\hline Positive & & $\begin{array}{c}\mathrm{t}= \\
-11,596^{* * *}\end{array}$ & $\mathrm{t}=-9,752^{* * *}$ & $\mathrm{t}=-6,380^{* * *}$ & $\mathrm{t}=-8,310^{* * *}$ & $\mathrm{t}=2,183^{*}$ & $\mathrm{t}=-10,71^{* * *}$ \\
\hline Negative & $\begin{array}{c}\mathrm{t}= \\
-11,596^{* * *}\end{array}$ & & $\mathrm{t}=-0,345$ & $\mathrm{t}=5,653^{* * *}$ & $\mathrm{t}=2,456^{*}$ & $\begin{array}{c}\mathrm{t}= \\
-11,757^{* * *}\end{array}$ & $\mathrm{t}=0,024$ \\
\hline Sexual & $\mathrm{t}=-9,752^{* * *}$ & $\mathrm{t}=-0,345$ & & $\mathrm{t}=5,484^{* * *}$ & $\mathrm{t}=2,271^{*}$ & $\mathrm{t}=11,692^{* * *}$ & $\mathrm{t}=0,024$ \\
\hline Humorous & $\mathrm{t}=-6,380^{* * *}$ & $\mathrm{t}=5,653^{* * *}$ & $\mathrm{t}=5,484^{* * *}$ & & $\mathrm{t}=-3,382^{* * *}$ & $\mathrm{t}=7,528^{* * *}$ & $\mathrm{t}=-6,554^{* * *}$ \\
\hline $\begin{array}{l}\text { Resembling } \\
\text { road signs }\end{array}$ & $\mathrm{t}=-8,310^{* * *}$ & $\mathrm{t}=2,456^{*}$ & $\mathrm{t}=2,271^{*}$ & $\mathrm{t}=-3,382^{* * *}$ & & $\mathrm{t}=10,414^{* * *}$ & $\mathrm{t}=-2,632^{* *}$ \\
\hline Sales offers & $\mathrm{t}=2,183^{*}$ & $\begin{array}{c}\mathrm{t}= \\
-11,757^{* * *}\end{array}$ & $\mathrm{t}=11,692^{* * *}$ & $\mathrm{t}=7,528^{* * *}$ & $\mathrm{t}=10,414^{* * *}$ & & $\begin{array}{c}\mathrm{t}= \\
\mathrm{t}=0,024\end{array}$ \\
\hline Riddles & $\mathrm{t}=-0,024$ & $\mathrm{t}=-6,554^{* * *}$ & $\mathrm{t}=-2,632^{* *}$ & $\begin{array}{c}\mathrm{t}= \\
-10,71^{* * *}\end{array}$ & $\mathrm{t}=0,270^{* * *}$ & \\
\hline
\end{tabular}

$* \mathrm{p}<0,05 \quad * * \mathrm{p}<0,01 \quad * * * \mathrm{p}<0,001$

Table 4. Age and driving experience correlation with declared frequency of distraction experienced from advertisements.

\begin{tabular}{|c|c|c|c|c|c|c|c|}
\hline & Positive & Negative & Sexual & Humorous & $\begin{array}{c}\text { Resembling } \\
\text { road signs }\end{array}$ & $\begin{array}{c}\text { Sales } \\
\text { offers }\end{array}$ & Riddles \\
\hline Age & $\begin{array}{c}\mathrm{r}= \\
-0,108 * * *\end{array}$ & $\mathrm{r}=-0,045$ & $\mathrm{r}=-0,093 * *$ & $\begin{array}{c}\mathrm{r}= \\
-0,121^{* * *}\end{array}$ & $\mathrm{r}=-0,080 * *$ & $\mathrm{r}=-0,004$ & $\mathrm{r}=-0,080 * *$ \\
\hline $\begin{array}{c}\text { Length of } \\
\text { driing } \\
\text { experience }\end{array}$ & $\mathrm{r}=-0,101 * *$ & $\mathrm{r}=-0,103 * *$ & $\mathrm{r}=-0,081 * *$ & $\begin{array}{c}\mathrm{r}= \\
-0,112 * * *\end{array}$ & $\begin{array}{c}\mathrm{r}= \\
-0,120^{* * *}\end{array}$ & $\begin{array}{c}\mathrm{r}= \\
-0,081 * *\end{array}$ & $\begin{array}{c}\mathrm{r}= \\
-0,119 * * *\end{array}$ \\
\hline
\end{tabular}

$* \mathrm{p}<0,05 \quad * * \mathrm{p}<0,01 \quad * * * \mathrm{p}<0,001$

\section{Study II}

The aim of the study was to verify the impact of emotionally loaded advertisements on attention focus [16].

\subsection{Participants and procedure}

The study was conducted on 50 (23 female and 27 male) Polish amateur drivers aged from 21 to $51(\mathrm{M}=27, \mathrm{SD}=5.72)$. All of them held their driving license for at least one year $(\mathrm{M}=7.8$; $\mathrm{SD}=5.72)$, the mean amount of yearly driven kilometres was $9907(\mathrm{SD}=15161)$.

A two-task attention test was constructed. The stimuli took the form of a Power Point presentation consisting of a simplified version of Wittenborn test cited after Zomeren and Brouwer [17]. The task consisted of three digits located centrally on the slide. In three corners of the slide, 5-9 simple geometric figures were located, the number of figures was chosen according to the capacity of working memory [18]. The fourth corner was used to display a picture, which was either an advertisement ( 4 items emotionally positive, 6 - negative, $10-$ neutral) or a non-advertisement emotionally neutral picture (10 items). Each participant was presented 3 training and 30 test slides, single exposition lasted 2 seconds. After each slide, they were asked whether the digits were arranged in ascending or descending order and how many triangles they saw in the slide. The amount of correct answers (scores ranged $0-1$ ) served as a performance measure. 


\subsection{Results}

ANOVA analysis did not reveal any statistically significant differences between different stimuli conditions for the simplified Wittenborn task $(\mathrm{F}(3)=0.99 ; \mathrm{p}=0.39)$. For the figures counting task, some effects of conditions were identified $(F(3)=3.55 ; p=0.01)$. Post hoc analysis with $\mathrm{T}$-test for dependent samples revealed that the test scores in positive advertisement condition were significantly lower than in negative and non-advertisement neutral picture condition. The difference between positive and neutral advertisements did not reach $\mathrm{p}<0,05$ significance level, however, a statistical trend in the same direction was present $(\mathrm{p}=0,066)$. Mean values for the figure counting test are presented in Table 5, and t-test values, are presented in Table 6 .

Table 5. Figure counting test scores in the context of different advertisement content.

\begin{tabular}{|l|c|c|c|c|}
\hline & Positive & Negative & Neutral & $\begin{array}{c}\text { Neutral non- } \\
\text { advertisements }\end{array}$ \\
\hline Mean & 0,58 & 0,65 & 0,65 & 0,68 \\
\hline Standard deviation & 0,27 & 0,26 & 0,21 & 0,18 \\
\hline
\end{tabular}

Table 6. Advertisement content and attention test results.

\begin{tabular}{|l|c|c|c|c|}
\hline & Positive & Negative & Neutral & $\begin{array}{c}\text { Neutral non- } \\
\text { advertisements }\end{array}$ \\
\hline Positive & & $\mathrm{t}=2,158^{*}$ & $\mathrm{t}=1,881$ & $\mathrm{t}=2,953^{*}$ \\
\hline Negative & $\mathrm{t}=2,158^{*}$ & & $\mathrm{t}=0,04$ & $\mathrm{t}=0,913$ \\
\hline Neutral & $\mathrm{t}=1,881$ & $\mathrm{t}=0,04$ & & $\mathrm{t}=1,219$ \\
\hline $\begin{array}{l}\text { Neutral non- } \\
\text { advertisements }\end{array}$ & $\mathrm{t}=2,953^{*}$ & $\mathrm{t}=0,913$ & $\mathrm{t}=1,219$ & \\
\hline
\end{tabular}

$* \mathrm{p}<0,05$

\section{General Discussion}

Consistently with previous research, roadside advertisements attract attention of most of the drivers, with more than a quarter of them declaring that it happens often, and only $5.7 \%$ that they never pay attention. Even more compelling, one in five drivers declares frequent conscious reading of the advertisements' content while driving. Some contents of roadside advertisements are subjectively more distracting than others. It seems, that the most subjectively distracting ones are those with emotionally negative contents, sexual contents, and riddles. Experimental data, however, revealed something opposite to the subjective feeling, namely the negative influence of emotionally positive advertising content on attention test performance, though it seems to affect attention to peripherally presented stimuli only (essential for maintaining situational awareness [19]). One thing remains clear which is the fact that emotional value of advertisement content affects drivers' attention which leads us to a conclusion that further experimental research on drivers' attention detachment from the road in the presence of advertisements of different emotional value might be beneficial.

Age-involving analyses justify the hypothesis that distraction from roadside advertising may be particularly dangerous for novice drivers who have not yet fully automatized driving operations and thus need to devote more attention to driving. As long as this seems to be the 
truth on the level of subjective feelings, experimental verification of this hypothesis might be useful.

\section{Acknowledgements}

The research and the preparation of this article were funded by the National Centre for Research and Development and the General Director for National Roads and Motorways ( DZP/RID/I33/4/NCBR/2016).

\section{References}

1. G. Yannis, E. Papadimitriou, P. Papantoniou, C. Voulgari, A statistical analysis of the impact of advertising signs on road safety, Int. J. Inj. Contr. Saf. Promot. 20 pp. 111120 (2013). doi:10.1080/17457300.2012.686042

2. A. Smiley, B. Persaud, G. Bahar, C. Mollett, C. Lyon, T. Smahel, W. Kelman, Traffic Safety Evaluation of Video Advertising Signs, Transp. Res. Rec. J. Transp. Res. Board. 1937 pp. 105-112 (2005). doi:10.3141/1937-15

3. P. Izadpanah, R. Omrani, S. Koo, A. Hadayeghi, Effect of Static Electronic Advertising Signs on Road Safety, J. Orthop. Trauma. 28 pp. S33-S36 (2014). doi:10.1097/BOT.0000000000000101

4. S. Bendak, K. Al-Saleh, The role of roadside advertising signs in distracting drivers, Int. J. Ind. Ergon. 40 pp. 233-236 (2010). doi:10.1016/j.ergon.2009.12.001

5. M.S. Young, J.M. Mahfoud, N.A. Stanton, P.M. Salmon, D.P. Jenkins, G.H. Walker, Conflicts of interest: The implications of roadside advertising for driver attention, Transp. Res. Part F Traffic Psychol. Behav. 12 pp. 381-388 (2009). doi:10.1016/j.trf.2009.05.004

6. T. Horberry, J. Anderson, M.A. Regan, T.J. Triggs, J. Brown, Driver distraction: The effects of concurrent in-vehicle tasks, road environment complexity and age on driving performance, Accid. Anal. Prev. 38 pp. 185-191 (2006). doi:10.1016/j.aap.2005.09.007

7. J. Edquist, T. Horberry, S. Hosking, I. Johnston, Effects of advertising billboards during simulated driving, Appl. Ergon. 42 pp. 619-626 (2011). doi:10.1016/j.apergo.2010.08.013

8. D. Belyusar, B. Reimer, B. Mehler, J.F. Coughlin, A field study on the effects of digital billboards on glance behavior during highway driving, Accid. Anal. Prev. 88 pp. 88-96 (2016). doi:10.1016/j.aap.2015.12.014

9. D. Crundall, E. Van Loon, G. Underwood, Attraction and distraction of attention with roadside advertisements, Accid. Anal. Prev. 38 pp. 671-677 (2006). doi:10.1016/j.aap.2005.12.012

10. D. Kaber, C. Pankok, B. Corbett, W. Ma, J. Hummer, W. Rasdorf, Driver behavior in use of guide and logo signs under distraction and complex roadway conditions, Appl. Ergon. 47 pp. 99-106 (2015). doi:10.1016/j.apergo.2014.09.005

11. Y. Zhang, E. Harris, M. Rogers, D. Kaber, J. Hummer, W. Rasdorf, J. Hu, Driver distraction and performance effects of highway logo sign design, Appl. Ergon. 44 pp. 472-479 (2013). doi:10.1016/j.apergo.2012.10.009

12. F. Schieber, K. Limrick, R. McCall, A. Beck, Evaluation of the Visual Demands of Digital Billboards Using a Hybrid Driving Simulator, Proc. Hum. Factors Ergon. Soc. Annu. Meet. 58 pp. 2214-2218 (2014). doi:10.1177/1541931214581465

13. K. Oatley, J.M. Jenkins, Zrozumieć emocje (Wydawnictwo Naukowe PWN, Warszawa, 
2003)

14. A. Megías, L.L. Di Stasi, A. Maldonado, A. Catena, A. Cándido, Emotion-laden stimuli influence our reactions to traffic lights, Transp. Res. Part F Traffic Psychol. Behav. 22 pp. 96-103 (2014). doi:10.1016/j.trf.2013.09.017

15. A. Megías, A. Maldonado, A. Cándido, A. Catena, Emotional modulation of urgent and evaluative behaviors in risky driving scenarios, Accid. Anal. Prev. 43 pp. 813-817 (2011). doi:10.1016/j.aap.2010.10.029

16. K. Ziętek, Unpublished master thesis: Wpływ ładunku emocjonalnego reklam na koncentrację uwagi wzrokowej, University of Warsaw, 2016

17. A.H. Zomeren, W.H. Brouwer, Clinical neuropsychology of attention (Oxford University Press, 1994)

18. A. Baddeley, D. Chincotta, L. Stafford, D. Turk, Is the word length effect in STM entirely attributable to output delay? Evidence from serial recognition, Q. J. Exp. Psychol. Sect. A. 55 pp. 353-369 (2002). doi:10.1080/02724980143000523

19. A. Tarnowski, Eye Movements as the Window into Visual Attention Mechanisms and Situation Awareness, Polish J. Aviat. Med. Psychol. 18 pp. 45-50 (2012) 